\title{
EFFECT OF ARBUSCULAR MYCORRHIZAL FUNGI, NPK COMPLETE FERTILIZERS ON GROWTH AND CONCENTRATION NUTRIENTS OF ACCLIMATIZED DATE PALM PLANTLETS
}

Abo- Rekab, Z.A

Horticulture research institute
Darwesh, R.S.S

Hassan, N.

Central laboratory of Date palm for development and research, Agriculture Research Center

\begin{abstract}
This work was done in 2008-2009 seasons to study the positive effects of Arbuscular mycorrhizal fungi on growth and absorption of macro and micro elements by plantlets of date palm (Phoenix dactylifera L.cv Bartomouda). Plantlets were produced via tissue culture technique. One year after acclimatization stage, the roots of potted plantlets were inoculated with arbuscular mycorrhizal fungi (Glomus spore), they were fertilized with NPK (Krestalon) complete fertilizers (19-19-19) with three different levels, i.e. 1.5, 2.0 and $2.5 \mathrm{~g} / 1$, in addition to control treatment. Plantlets were weekly fertilized for eight month during two seasons. The results of both seasons indicated that of inoculation mycorrhizal fungi induced positive effects of growth and minerals content. The addition of $2.5 \mathrm{~g} / \mathrm{l}$ NPK had the highest significant values of plant height $(\mathrm{cm})$, number of leaves/ plantlet, length of root $(\mathrm{cm})$, and number of roots/plantlet as compared to control treatment. Arbuscular mycorrhizal fungi showed a network of hyphae around roots which might increase water, macro and micro nutrients the absorption through increasing the absorption surface area. The results also revealed that there were significant differences among different NPK treatments on various growth parameters and minerals contents. Nitrogen, phosphorus, potassium, $\mathrm{Fe}, \mathrm{Zn}, \mathrm{Mn}$ and $\mathrm{Cu}$, were significantly increased with the three applications all studied fertilized levels. These data showed that the inoculation of mycorrhizal had positive effects on absorption of macro and micro minerals which could be reflected on photosynthesis and this was appeared in the form of new leaves and roots of the plants (growth), also the application of soil with mycorrhiza had decreased the dose of fertilizers were used in the culture which to be inverted to the economic cultures.
\end{abstract}

\section{INTRODUCTION}

Many investigators demonstrated that Arbuscular mycorrhizal increased the absorbtion of nutrient elements through its hypha and transport them to the plant, Egertone et al.(2009) on grass land Mona on banana and guava (2001), George et al. (1992), Thingstrup et al. (1999)on Linum usitatissimum and Bakhshipour et al. (2008) on tea seedlings indicated that Arbuscular mycorrhizal enhanced plant uptake of inorganic nutrients particularly phosphorus and nitrogen. This incessant uptake resulted in better growth. Eliopoulos et al(2007). on potato, Chen et al. (2007), Gergon et al(2008). on Allium cepa, Schubert et al(2009). on Actinidia deliciosa, Peter et al(2009). on Pinus muricataand Ahmed et al(2009) on cucumber found that mycorrhizal inoculation and NPK fertilizers (120- 240- $120 \mathrm{~kg} \mathrm{NPK} / \mathrm{ha})$ and $(60-120-60 \mathrm{~kg} / \mathrm{ha}$ NPK) increased growth. Since the date palm is economically very important in Egypt and their growth is very slow especially produced through micropropagation and since the most date palm orchards did not take enough care.

Received 23/9/2010 accepted 4/10/2010 
Thus the principal objective of this investigation is to evaluate the growth and the absorption of NPK in which mycorrhizal fungus inoculation under soil of date palm plantlets in the greenhouse.

\section{MATRRIALS AND METHODS}

This investigation was conducted during 2008 and 2009 seasons in the greenhouse of the Horticultural Research Institute, Giza, Egypt. The plantlets (Phoenix dactylifera $\mathrm{L}$. cv Bartomouda) which produced through tissue culture after they passed rooting stage $(1 / 4 \mathrm{MS}+0.1 \mathrm{IBA})$ for one month, one year after acclimatization stage, plantlets were selected with same characterized (3-4 leaves, $20-25 \mathrm{~cm}$ of shoot length $15-18 \mathrm{~cm}$ for root length) and were cultivated in peat moss (which is poor of macro elements, riche in organic matter (Central Lab of Horticulture research institute ARC), and used to increase soil capacity to hold water and nutrients by increasing capillary forces and cation exchange capacity) and sand 2:1 in the plastic bags $(40 \mathrm{x} 20 \mathrm{~cm})$. Three NPK levels, i.e. 1.5,2.0 and $2.5 \mathrm{~g} / 1$ of complete fertilizers (krestalon 19-19-19), in addition to control treatment (water only)were uesd. Each treatment was replicated three times, and each one contains three plantlets. These plantlets were fertigated weekly for eight months during two seasons were of this experiment.

Mycorrhizal treatment:Mycorrhizal spores were originally extracted from the Egyptian soil spores of arbuscular mycorrhizal (VAM) fungi including the following genera (Glomus Giga spora and Acaulo spora) were added after planting. Extraction and method was described by (Massoud 1999), fifty grams (250 spores/gram) per pot of mixed spores of arbuscular mycorrhizal genera were prepared after extraction and the roots of plantlets of each pot were immersed in sugary solution then coated with Mycorrhizal spores carried on sterilized sand soil was modified (Massoud 2005). The following parameters were estimated at the end of the experiment (eight months).

1- Number leaves /plantlet 2- Plant height $(\mathrm{cm}) \quad 3$ - Root length $(\mathrm{cm})$

4- Number roots /plantlet 5- Fresh and dry weights of leaves (the fresh leaves sampling was cut into small parts and dried at $60-65 \mathrm{c}^{0}$ for $48 \mathrm{~h}$ to obtain the dry matter content according to Dowson and Aten (1962).

Total sugars.According to Dubois et al.(1956) and by means of the standard curve of glucose.

Chemical analysis:- Mineral content $(\mathrm{N}, \mathrm{P}, \mathrm{K}, \mathrm{Fe}, \mathrm{Zn}, \mathrm{Mn}$ and $\mathrm{Cu})$ : Nitrogen was determined according to Koch and McMeekin (1924), Phosphorus and Potassium as described by Chapman and Parker (1961). Iron, manganese, zinc and copper concentrations were determined by using Atomic absorbtion spectrophotometer (Perkin Elmer 3300) according to AOAC (1980).

Anatomical study:Transverse cross sections were taken from the middle part of the main root (3-5 cm behind apex of the main root). Samples were killed and fixed in formalin, acetic acid and ethyl alcohol, at a ratio of 90:5:5, dehydrated in ascending concentrations of ethyl alcohol, then cleared by soaking in a series of absolute alcohol and xylene and imbedded in paraffin wax (M.P. 55-58 oC). Using a rotary microtome, a serial cross-sections (15-20 microns) were taken. Samples were then stained with safraneen and light green combination and mounted in Canada balsam. 
Examination and observations were carried out by Nikon light Microscope and photographed by Nikon Camera FX-35.

Statistical analysis:- The complete randomized design was adopted for the experiment according to (Snedecor and Cochran 1980), the means were compared using L.S.D. values at $5 \%$ level.

\section{RESULTS AND DISCUSSION}

Growth parameters of date palm Phoenix dactylifera 1 . i.e. plant height, number of leaves, root length and numbers of roots were presented in Table (1). As for the number of leaves data in Table (1) illustrated that The treatment $1.5 \mathrm{NPK}$ with mycorhiza produced the lowest value of number of leaves/ plantlet (6.1 and 6.3 for the first and second season, respectively) as compared to control treatment (3.6 and 4.0 for the first and second season, respectively). The number of leaves of the plantlets were significant raised with $2.5 \mathrm{~g} / 1 \mathrm{NPK}$ (19-19-19) and inoculated with mycorrhizal fungi gave 7.2 and 7.8 leaves/plantlet for the first and second season respectively, as compared to control treatment (3.6 and 4.0 leaves/plantlet for the first and second season respectively). Significant differences were obtained from 2.0 and 2.5 treatments of complete fertilizer NPK on the number of leaves in which mycorrhiza was added. Concerning the effect of complete fertilizer NPK (1.5,2.0 and $2.5 \mathrm{~g} / \mathrm{l}$ ) and soil inoculation of arbuscular mycorrhizal fungi, on plantlet height, data in Table(1) and fig (1) revealed that significantly increased it was found with the three levels of NPK (89.9,92.6 and 96.5and 91.1,94.6 and 98.7 for first and second season respectively) with $1.5,2.0$ and $2.5 \mathrm{~g} / 1$ of complete fertilizer NPK as compared to control treatment and VAM, highly significant increase was obtained from addition $2.5 \mathrm{~g} / 1 \mathrm{NPK}(89.1$ and 91.0 with mycorrhiza. for first and second season, respectively)

Regarding the root length and number of roots: results in Table (2) indicated that significant enhancement on root length 50.5 and $52.6 \mathrm{~cm}$ for the first and second seasons, respectively for the treatment $1.5 \mathrm{~g} / 1 \mathrm{NPK}$ with mycorrhiza, while the treatment $2.5 \mathrm{~g} / 1 \mathrm{NPK}$ resulted in the greatest root length 65.2 and $66.3 \mathrm{~cm}$ for the first and second seasons, respectively, as compared to control treatment (water only). Highly significant interaction was found between complete fertilizer and mycorrhiza on the root length.

From the Table (2) the number of roots were took the same trend of the root length. Interaction between VAM and the treatment $2.5 \mathrm{~g} / 1 \mathrm{NPK}$ were produced the highest significant values of roots number ( 7.6 and 8.5 roots/plantlet for first and second season respectively) compared to control treatment (water only) which was gave the lowest values 4.8 and 5.1 roots/plantlet for the first and second seasons, respectively,. In this respect, (Duponnois et al. 2007) stated that arbuscular mycorrhizal (Glomus intraradices) was significant enhanced plant growth and height plants of Acacia holosericea. Growth and shoot length of Eucalyptus globules were increased with saprob and arbuscular mycorrhizal fungi (Arriagada et al. 2007). Number of leaves of Sesamum indicum L. and root system were higher with addition of arbuscular mycorrhizal fungi to the soil (Boureima et al. 2008). Plant growth of Conifers was increased with inoculation with arbuscular mycorrhizal and fertilized with $27 \mathrm{~kg} \mathrm{~N} / \mathrm{ha}+39 \mathrm{Pkg} / \mathrm{ha}$ (Classen and Zasoski 2009). 
Table (1): Effect of mycorrhiza and different levels ofcomplete fertilizers on leaves number/plantlet and plant height $(\mathrm{cm})$ of Phoenix dactylifera $\mathrm{L}$. cv. Bartomouda at 2008-2009 seasons.

\begin{tabular}{|c|c|c|c|c|c|c|c|c|c|c|c|c|}
\hline \multirow{3}{*}{$\begin{aligned} & \mathbf{A} \\
\mathbf{B} & \end{aligned}$} & \multicolumn{6}{|c|}{ Leaves number } & \multicolumn{6}{|c|}{ Plant height(cm) } \\
\hline & \multicolumn{3}{|c|}{ First season } & \multicolumn{3}{|c|}{ Second season } & \multicolumn{3}{|c|}{ First season } & \multicolumn{3}{|c|}{ Second season } \\
\hline & con & mycorrh & mean & con & mycorrh & mean & con & mycorrh & Mean & Con & Mycorrh & Mean \\
\hline Con & 3.6 & 4.8 & 4.2 & 4 & 5.6 & 4.8 & 70.6 & 79.5 & 75.1 & 74.5 & 77.8 & 76.2 \\
\hline 1.5 & 4.9 & 6.1 & 5.5 & 5.3 & 6.3 & 5.8 & 76.3 & 89.9 & 83.1 & 77.7 & 91.1 & 84.4 \\
\hline 2.0 & 5.2 & 6.4 & 5.8 & 5.8 & 6.8 & 6.3 & 79.3 & 92.6 & 86 & 80.7 & 94.6 & 87.7 \\
\hline Mean & 4.9 & 6.1 & & 5.4 & 6.6 & & 77.0 & 89.6 & & 79.0 & 90.6 & \\
\hline $\begin{array}{c}\text { l.s.d. } \\
(0.05 \%)\end{array}$ & \multicolumn{3}{|c|}{$\begin{array}{c}\mathrm{A}=0.3 \quad \mathrm{~B}=0.2 \\
\mathrm{AB}=0.4\end{array}$} & \multicolumn{3}{|c|}{$\begin{array}{c}\mathrm{A}=0.4 \quad \mathrm{~B}=0.3 \\
\mathrm{AB}=0.6\end{array}$} & \multicolumn{2}{|c|}{$A=1.5$} & $\mathbf{A B}=\mathbf{2 . 0}$ & \multicolumn{2}{|c|}{$\mathrm{A}=1.4$} & $\mathrm{AB}=1.9$ \\
\hline
\end{tabular}

$\mathrm{A}=\mathrm{NPK} \quad \mathrm{B}=$ mycorrhiza $\mathrm{AB}=\mathrm{NPK} \mathrm{X}$ mycorrhiza

Table (2): Effect of mycorrhiza and different levels of complete fertilizers on root length $(\mathrm{cm})$ and root number /plantlet of Phoenix dactylifera L. cv Bartomouda at 2008- 2009 seasons.

$\mathrm{A}=\mathrm{NPK} \quad \mathrm{B}=$ mycorrhiza $\quad \mathrm{AB}=\mathrm{NPK} \mathrm{X}$ mycorrhiza

\begin{tabular}{|c|c|c|c|c|c|c|c|c|c|c|c|c|}
\hline \multirow[b]{3}{*}{$\mathbf{A}$} & \multicolumn{6}{|c|}{ Root length (cm) } & \multicolumn{6}{|c|}{ Root number } \\
\hline & \multicolumn{3}{|c|}{ First season } & \multicolumn{3}{|c|}{ Second season } & \multicolumn{3}{|c|}{ First season } & \multicolumn{3}{|c|}{ Second season } \\
\hline & con & mycorrh & mean & con & mycorrh & Mean & con & mycorrh & Mean & Con & mycorrh & Mean \\
\hline Con & 39.5 & 52.2 & 45.9 & 40.5 & 53.5 & 47.0 & 4.8 & 5.6 & 5.2 & 5.1 & 5.9 & 5.5 \\
\hline 1.5 & 44.4 & 56.5 & 50.5 & 46.5 & 58.7 & 52.6 & 6.2 & 6.5 & 6.4 & 6.6 & 6.8 & 6.7 \\
\hline 2.0 & 47.1 & 60.8 & 54.0 & 48.4 & 61.8 & 55.1 & 6.8 & 7.0 & 7.0 & 7.4 & 7.4 & 7.4 \\
\hline 2.5 & 50.6 & 65.2 & 57.9 & 52.2 & 66.3 & 59.3 & 7.5 & 7.6 & 7.6 & 7.8 & 8.5 & 8.2 \\
\hline Mean & 45.4 & 58.7 & & 46.9 & 60.1 & & 6.3 & 6.7 & & 6.7 & 7.2 & \\
\hline $\begin{array}{c}\text { l.s.d. } \\
(\mathbf{0 . 0 5 \% )})\end{array}$ & $\mathrm{A}=1.1$ & $\mathrm{~B}=0.8$ & $A B=1.6$ & $\mathrm{~A}=1.4$ & $\mathrm{~B}=0.9$ & $A B=1.9$ & $\mathbf{A}=\mathbf{0 . 4}$ & $\mathrm{B}=0.3$ & $\mathrm{AB}=0.5$ & $\mathrm{~A}=0.4$ & $\mathrm{~B}=0.2$ & $\mathrm{AB}=0.5$ \\
\hline
\end{tabular}

Three species of arbuscular mycorrhizal (Glomus mosseae, Gigaspora margarita and Gigaspora rosea), the Gigaspora rosea significantly increased internodes number of Ocimum basilicum var. Genovese (Copetta et al. 2009).

Fresh and dry weights of leaves:_Regarding to the effect of inoculation of arbuscular mycorrhizal and three levels of complete fertilizer NPK 19-19-19 $(1.5,2.0$ and $2.5 \mathrm{~g} / \mathrm{l})$ on the fresh and dry weights of leaves of date palm. Data in the Table (3) indicated that all levels of complete NPK and arbuscular mycorrhizal were significantly enhanced fresh and dry weights of leaves for both seasons as compared to control treatment (water only) which was induced the lowest values 8.5, 9.4 and 3.8, $4.3 \mathrm{gm}$. respectively for fresh and dry weights of leaves in the first and second seasons, while the highest values were obtained by the treatment $2.5 \mathrm{~g} / 1$ complete fertilizer with mycorrhiza treatment (17.4,18.1 and 8.3, 8.5 gm.respectively for fresh and dry weights of the first and second seasons, respectively). These findings were supported by (Cline et al. 2007) who stated that root to shoot biomass ratio of Douglas fir (Pseudotsuga menziesii (Mirb).Franco) seedlings were significantly greater with ectomycorrhiza fungi. (Ben et al. 2008) found that date palm (Phoenix dactylifera L.) dry weights were increased by about $57 \%$ with inoculated by arbuscular mycorrhizal fungi. Ail et al. (2008) showed that more biomass of Koeleria pyramidata and Poe pratensis were accumulated with arbuscular 
mycorrhizal. Recently (Chen et al. 2009) cleared that arbuscular mycorrhizal increased plant dry weights of shoots of Medicago sativa and Plantago lanceolata when fertilized by $\mathrm{N}$ fertilizer, (Covacevich et al 2009) stated that shoot dry matter of Triticum aestivum was increased with AM. These previous data indicated that the useful effect of mycorrhiza on the concentrations of macro and micro nutrients which taking up from the soil by the plants which is shown as growth of leaves and roots which were closely related to photosynthesis in the green plants.

Table (3): Effect of mycorrhiza and different levels of complete fertilizers on fresh and dry weights (gm) of Phoenix dactylifera L. plantlets cv Bartomouda at 2008-2009 seasons.

\begin{tabular}{|c|c|c|c|c|c|c|c|c|c|c|c|c|}
\hline \multirow[b]{3}{*}{$\mathbf{A}$} & \multicolumn{6}{|c|}{ Fresh weight (gm) } & \multicolumn{6}{|c|}{ Dry weight(gm) } \\
\hline & \multicolumn{3}{|c|}{ First season } & \multicolumn{3}{|c|}{ Second season } & \multicolumn{3}{|c|}{ First season } & \multicolumn{3}{|c|}{ Second season } \\
\hline & con & mycorrh & mean & con & mycorrh & Mean & con & mycorrh & Mean & Con & mycorrh & Mean \\
\hline Con & 8.5 & 9.1 & 4.6 & 9.4 & 9.9 & 9.7 & 3.8 & 5.1 & 4.5 & 4.3 & 5.4 & 4.9 \\
\hline 1.5 & 13.9 & 13.5 & 13.7 & 15.0 & 14.6 & 14.8 & 5.6 & 6.3 & 6.0 & 6.2 & 6.7 & 6.5 \\
\hline 2.0 & 15.4 & 15.2 & 15.3 & 16.1 & 15.9 & 16.0 & 6.3 & 7.0 & 6.7 & 6.7 & 7.1 & 7.1 \\
\hline 2.5 & 16.7 & 17.4 & 17.1 & 17.1 & 18.1 & 17.6 & 7.4 & 8.3 & 7.9 & 7.6 & 8.5 & 8.5 \\
\hline Mean & 14.4 & 14.6 & & 14.4 & 14.6 & & 5.8 & 6.7 & & 6.2 & 7.3 & \\
\hline $\begin{array}{c}\text { l.s.d. } \\
(\mathbf{0 . 0 5 \%})\end{array}$ & $A=0.6$ & $B=0.4$ & $\mathrm{AB}=0.8$ & $A=1.1$ & $\mathrm{~B}=0.9$ & $A B=1.7$ & $\mathbf{A}=\mathbf{0 . 3}$ & $\mathrm{B}=0.2$ & $\mathrm{AB}=0.4$ & $A=0.5$ & $B=0.4$ & $\mathbf{A B}=\mathbf{0 . 7}$ \\
\hline
\end{tabular}

$\mathrm{A}=\mathrm{NPK} \quad \mathrm{B}=$ mycorrhiza $\mathrm{AB}=\mathrm{NPK} \mathrm{X}$ mycorrhiza

Total sugars $\mathbf{m g} / \mathbf{g}$ d.w.: As shown in the Table (4) arbuscular mycorrhizal inoculation and treatments of complete NPK $(1.5,2.0$ and $2.5 \mathrm{~g} / \mathrm{l})$ were increased significant the total sugars in the leaves of date palm plantlets, The treatment $2.5 \mathrm{~g} / 1$ NPK resulted in the greater content of total sugars compared to control treatment which had the lowest values of total sugars (45.0 and $45.8 \%$ in the two seasons respectively). and high significant interaction between treatments of NPK fertilizer and mycorrhiza. The previous results were in agreement with Demir (2004) showed that pepper plants which were infected with mycorrhizal fungus Glomus increased sucrose and total sugars contents, recently Bahadur et al. (2009) found that total sugars were increased with arbuscular mycorrhizal and organic manure and bio fertilizer (eitherphosphate solubilizing) in the Chinese cabbage (Brassica pekinensis (Lour) Rupe).

$\mathbf{N}, \mathbf{P}, \mathbf{K}, \mathbf{F e}, \mathbf{Z n}, \mathbf{M n}$ and $\mathrm{Cu}$ concentrations :-_Nitrogen $(\mathrm{N})$ and phosphorus $(\mathrm{P})$ were essential nutrients and they represented one of the most limiting in natural habitats as well as in agricultural production world-wide. Data in the Tables $(4,5,6$ and 7) and fig (2 and 3) exhibited that The treatment of $2.5 \mathrm{~g} / 1$ complete fertilizer was superior as compared to control treatment (water only). The treatment $1.5 \mathrm{~g} / 1$ had the lowest significant values as compared to control treatment, all treatments of complete fertilizer (1.5,2.0 and 2.5 g/l) NPK 19-19-19 and in combination with soil inoculation of arbuscular mycorrhizal were significantly increased the concentrations of nitrogen, phosphorus, potassium, and also the micronutrients $\mathrm{Fe}$, $\mathrm{Zn}, \mathrm{Mn}$ and $\mathrm{Cu}$ in the leaves of date palm. Highly significant greatest contents of these important minerals $\mathrm{N}, \mathrm{P}, \mathrm{K}, \mathrm{Fe}, \mathrm{Zn}, \mathrm{Mn}$ and $\mathrm{Cu}$ which were important for the plant growth. In this concerning (Bucher 2007) indicated that arbuscular mycorrhizal exhibited improved $\mathrm{P}$ acquisition efficiency and thus require lower 
inputs of P fertilizer for optimal growth. Cartmill et al. (2008) stated that N,P , K, Fe and $\mathrm{Zn}$ content were higher with arbuscular mycorrhizal of Rosa multiflora. Also Joner (2000) and Deguchi et al. (2007) on Trifolium repense, Al-Agely and Sylvia (2008) on Sea oats, and Cavagnaro et al. (2009) on Solanum lycopersicum found that N,P and Zn were increased with AM. The above results explain the important role of arbuscular mycorrhizal for fixing nitrogen which had the most favorable effects on the plants metabolism, therefore enhancing the other growth parameters.

Table (4): Effect of mycorrhiza and complete fertilizers on total sugars $\mathrm{mg} / \mathrm{g}$ d.w. and nitrogen $(\mathrm{g} / 100 \mathrm{~g}$ d.w) Contents of Phoenix dactylifera L. plantlets cv Bartomouda at 2008 and 2009 seasons.

\begin{tabular}{|c|c|c|c|c|c|c|c|c|c|c|c|c|}
\hline \multirow{3}{*}{$\mathbf{A} \mathbf{B}$} & \multicolumn{6}{|c|}{ Total sugars mg/g d.w. } & \multicolumn{6}{|c|}{ Nitrogen $g / 100 \mathrm{~g}$} \\
\hline & \multicolumn{3}{|c|}{ First season } & \multicolumn{3}{|c|}{ Second season } & \multicolumn{3}{|c|}{ First season } & \multicolumn{3}{|c|}{ Second season } \\
\hline & con & mycorrh & mean & con & mycorrh & mean & con & mycorrh & Mean & $\operatorname{con}$ & mycorrh & Mean \\
\hline Con & 45.0 & 69.4 & 57.2 & 45.8 & 69.4 & 57.6 & 1.8 & 2.4 & 2.1 & 2.1 & 2.6 & 2.4 \\
\hline 1.5 & 72.3 & 68.5 & 70.4 & $\begin{array}{l}73.7 \\
\end{array}$ & 69.4 & 71.6 & 2.0 & 5.1 & 3.6 & 2.3 & 5.3 & 3.8 \\
\hline 2.0 & 75.6 & 75.9 & 75.8 & 76.6 & 76.9 & 76.8 & 2.2 & 6.0 & 4.1 & 2.5 & 6.5 & 4.5 \\
\hline 2.5 & 77.5 & 80.2 & 78.9 & 78.4 & 81.5 & 80.0 & 2.5 & 6.3 & 4.4 & 2.8 & 6.9 & 4.9 \\
\hline Mean & 67.6 & 73.5 & & 68.6 & 74.3 & & 2.1 & 4.9 & & 2.4 & 5.3 & \\
\hline $\begin{array}{c}\text { l.s.d. } \\
(0.05 \%)\end{array}$ & $A=0.9$ & $\mathrm{~B}=\mathbf{0 . 7}$ & $A B=1.3$ & $\mathbf{A}=1$. & $B=0.9$ & $\mathrm{AB}=1.8$ & $\mathbf{A}=\mathbf{0}$. & $\mathrm{B}=\mathbf{0 . 1}$ & $A B=0.1$ & $\mathbf{A}=\mathbf{0}$ & $\mathrm{B}=\mathbf{0 . 1}$ & $\mathrm{AB}=0.2$ \\
\hline
\end{tabular}

Table (5): Effect of mycorrhiza and complete fertilizers on $\mathrm{P}$ and $\mathrm{K} \mathrm{g} / 100 \mathrm{~g}$ d.w. of Phoenix dactylifera L. cv. Bartomouda plantlets at 2008-2009

\begin{tabular}{|c|c|c|c|c|c|c|c|c|c|c|c|c|}
\hline \multirow{3}{*}{$\mathbf{A}$ B } & \multicolumn{6}{|c|}{ Phosphorus g/100 g } & \multicolumn{6}{|c|}{ Potassium g/100g } \\
\hline & \multicolumn{3}{|c|}{ First season } & \multicolumn{3}{|c|}{ Second season } & \multicolumn{3}{|c|}{ First season } & \multicolumn{3}{|c|}{ Second season } \\
\hline & con & mycorrh & mean & con & mycorrh & mean & con & mycorrh & Mean & Con & mycorrh & Mean \\
\hline Con & 0.1 & 0.3 & 0.2 & 0.1 & 0.3 & 0.2 & 0.5 & 0.8 & 0.7 & 0.7 & 0.9 & 0.8 \\
\hline 1.5 & 1.1 & 1.1 & 1.1 & 1.4 & 1.3 & 1.4 & 2.4 & 3.8 & 3.1 & 3.2 & 4.2 & 3.7 \\
\hline 2.0 & 1.2 & 1.9 & 1.6 & 1.4 & 2.3 & 1.9 & 3.3 & 5.1 & 4.2 & 3.5 & 5.4 & 4.5 \\
\hline 2.5 & 1.4 & 2.4 & 1.9 & 1.5 & 2.7 & 2.1 & 3.5 & 5.3 & 4.4 & 3.9 & 5.7 & 4.8 \\
\hline Mean & 0.95 & 1.4 & & 1.1 & 1.7 & & 2.4 & 3.8 & & 2.8 & 4.1 & \\
\hline $\begin{array}{c}\text { l.s.d. } \\
(0.05 \%)\end{array}$ & $\mathrm{A}=\mathbf{0 . 1}$ & $B=0.1$ & $A B=0.1$ & $\mathrm{~A}=\mathbf{0 . 1}$ & $\mathrm{B}=\mathbf{0 . 1}$ & $\mathrm{AB}=0.2$ & & $\begin{array}{r}=0.2 \quad B= \\
A B=0.4\end{array}$ & & $\mathbf{A}=\mathbf{0 . 2}$ & $\mathrm{B}=\mathbf{0 . 2}$ & $\mathrm{AB}=0.2$ \\
\hline
\end{tabular}

Table (6):Effect of mycorrhiza and different levels of complete fertilizers on Fe and Zn mg/l of Phoenix dactylifera L.cv. Bartomouda olantlets at 2008-2009

\begin{tabular}{|c|c|c|c|c|c|c|c|c|c|c|c|c|}
\hline \multirow{3}{*}{$\mathbf{A}$} & \multicolumn{6}{|c|}{ mg Fe.L. } & \multicolumn{6}{|c|}{ mg Zn. L. } \\
\hline & \multicolumn{3}{|c|}{ First season } & \multicolumn{3}{|c|}{ Second season } & \multicolumn{3}{|c|}{ First season } & \multicolumn{3}{|c|}{ Second season } \\
\hline & con & mycorrh & mean & con & mycorrh & mean & con & mycorrh & Mean & con & mycorrh & Mean \\
\hline Con & 36.4 & 39.8 & 38.1 & 37.5 & 39.5 & 38.5 & 30.5 & 31.1 & 30.8 & 30.5 & 31.7 & 31.1 \\
\hline 1.5 & 39.7 & 91.3 & 65.5 & 40.1 & 92.4 & 66.3 & 30.3 & 37.5 & 33.9 & 31.0 & 38.3 & 34.7 \\
\hline 2.0 & 42.1 & 110.3 & 76.2 & 43.0 & 110.6 & 76.8 & 35.2 & 39.8 & 37.5 & 36.8 & 40.2 & 38.5 \\
\hline 2.5 & 44.8 & 122.1 & 83.5 & 45.5 & 122.5 & 84.0 & 41.2 & 43.7 & 42.5 & 41.9 & 44.2 & 43.1 \\
\hline Mean & 40.8 & 90.9 & & 41.5 & 91.3 & & 34.4 & 38.0 & & 35.1 & 38.6 & \\
\hline $\begin{array}{c}\text { l.s.d. } \\
(0.05 \%)\end{array}$ & $A=1.1$ & $\mathrm{~B}=0.8$ & $\mathrm{AB}=1.5$ & $\mathrm{~A}=0.9$ & $B=0.6$ & $\mathrm{AB}=1.2$ & $A=0.6$ & $B=0.5$ & $\mathbf{A B}=0.9$ & $\mathrm{~A}=1$. & $\mathrm{B}=0.7$ & $\mathrm{AB}=1.4$ \\
\hline
\end{tabular}

$\mathrm{A}=\mathrm{NPK} \quad \mathrm{B}=$ mycorrhiza $\mathrm{AB}=\mathrm{NPK} \mathrm{X}$ mycorrhiza 
Table (7): Effect of mycorrhiza and different levels of complete fertilizers on Mn and $\mathrm{Cu} \mathrm{mg/l} \mathrm{of} \mathrm{Phoenix} \mathrm{dactylifera} \mathrm{L.} \mathrm{cv} \mathrm{Bartomouda} \mathrm{plantlets} \mathrm{at} \mathrm{2008-2009}$

\begin{tabular}{|c|c|c|c|c|c|c|c|c|c|c|c|c|}
\hline \multirow{3}{*}{ B } & \multicolumn{6}{|c|}{ mg Mn .L. } & \multicolumn{6}{|c|}{ mg Cu.L. } \\
\hline & \multicolumn{3}{|c|}{ First season } & \multicolumn{3}{|c|}{$\begin{array}{l}\text { Second season } \\
\end{array}$} & \multicolumn{3}{|c|}{ First season } & \multicolumn{3}{|c|}{ Second season } \\
\hline & con & mycorrh & mean & con & mycorrh & mean & con & mycorrh & Mean & con & mycorrh & Mean \\
\hline Con & 444.9 & 45.4 & 45.2 & 45.6 & 47.9 & \begin{tabular}{|l|}
46.8 \\
\end{tabular} & 6.9 & 7.5 & 7.2 & 7.5 & 7.9 & 7.7 \\
\hline 1.5 & 69.3 & 72.9 & 71.1 & 70.6 & 72.9 & 71.8 & 13.3 & 12.6 & 13.0 & 13.5 & 13.2 & 13.4 \\
\hline 2.0 & 87.8 & 89.4 & 88.6 & 89.4 & 90.6 & 90.0 & 14.2 & 14.8 & 14.5 & 14.5 & 15.4 & 15.0 \\
\hline 2.5 & 106 & 102.4 & 104.2 & 100.8 & 102.8 & 101.8 & 15.0 & 16.6 & 15.8 & 15.3 & 17.4 & 16.4 \\
\hline Mean & 77.0 & 77.5 & & 76.6 & 78.5 & & 12.4 & 12.9 & & 12.7 & 13.5 & \\
\hline $\begin{array}{c}\text { l.s.d. } \\
(0.05 \%)\end{array}$ & $\mathrm{A}=\mathbf{2 . 3}$ & $B=1.6$ & $\mathrm{AB}=3.3$ & $A=0.9$ & $B=0.6$ & $\mathrm{AB}=1.2$ & $\mathrm{~A}=0.2$ & $B=0.1$ & $\mathrm{AB}=0.3$ & $\mathrm{~A}=0.2$ & $B=0.1$ & $\mathrm{AB}=0.3$ \\
\hline
\end{tabular}

Anatomical study: The site of penetration is shown at top right of photos $(1,2,3$ and 4), where the fungus produced a pre-penetration swelling (appressorium, ap), then it grew between the root cells and formed finely branched arbuscules (arb) and swollen vesicles $(\mathrm{v})$.

The hyphae of AM fungi extend into soil, where their large surface area and efficient absorption enable them to uptake mineral nutrients, even if these are in short supply or are relatively immobile. AM fungi seemed to be particularly important for absorption of phosphorus, as a poorly mobile element, and a proportion of the phosphate that they absorbed has been shown to be passing into the plant

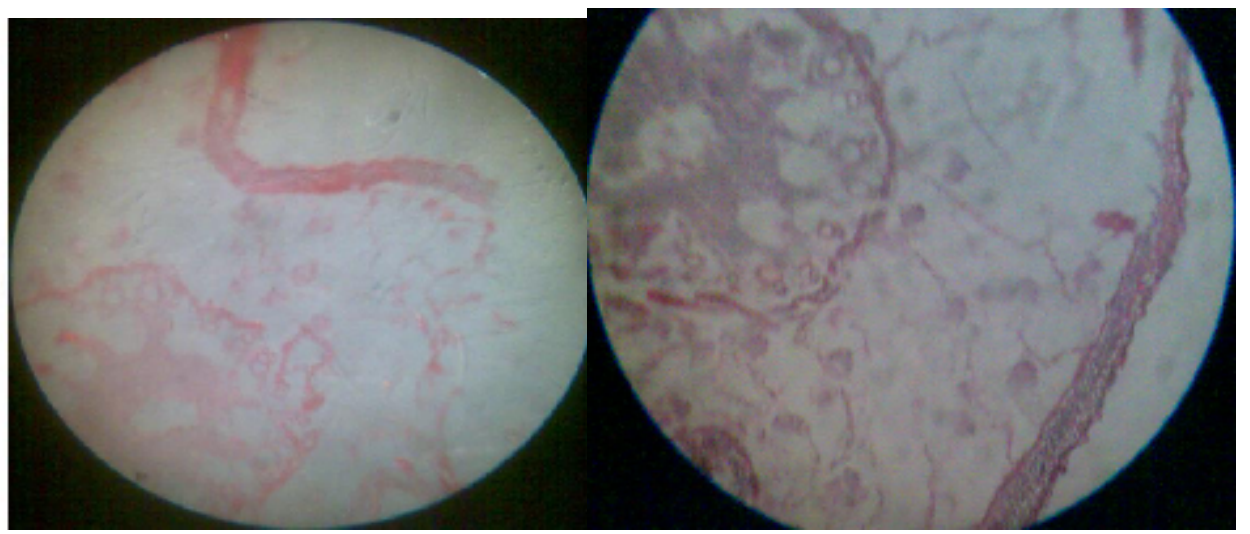

photo $(1,2)$

When arbuscular mycorrhizal fungal hyphae encounter the root of a host plant an apressorium (an infection structure) is form on the root epidermis. The apressorium is the structure from which the hyphae can penetrate into the host's parenchyma cortex. The formation of apressoria does not require chemical signals from the plant. AM fungi could form apressoria on the cell walls of "host" cells in which the protoplast had been removed to eliminate signaling between the fungi and the host plant. However, the hyphae did not further penetrate the cells and grew in toward the root cortex which indicates that signaling between symbionts could be required for further growth once appresoria are formed. Tillage breaking apart the soil macro structure the hyphae network is rendered non-infective (Miller et al. 1995, McGonigle and Miller 1999). The disruption of the hyphae network decreases 
the absorptive abilities of the mycorrhizae because the surface area spanned by the hyphae is greatly reduced, which in turn lowers the phosphorus input to the plants which are connected to the hyphal network, (McGonigle and Miller 1999). The available phosphorus concentration in the root zone could be increased by mycorrhizal activity. Mycorrhizae lower the rhizosphere $\mathrm{pH}$ due to selective uptake of $\mathrm{NH}_{4}{ }^{+}$(ammonium-ions) and release of $\mathrm{H}^{+}$ions. Decreased soil $\mathrm{pH}$ increased the solubility of phosphorus precipitates. The hyphae uptake of $\mathrm{NH}_{4}{ }^{+}$also increases the flow of nitrogen to plant. A decrease in mycorrhizal colonization due to high soil phosphorus levels can lead to plant deficiency in other micronutrients that have mycorrhizal mediated uptake such as copper (Timmer \& Leyden 1980).As the soil's phosphorus levels was available to the plants increase, the amount of phosphorus also increases in the plant's tissues and carbon drain on the plant by the AM fungi symbiosis become non-beneficial to the plant (Grant et al. 2005).
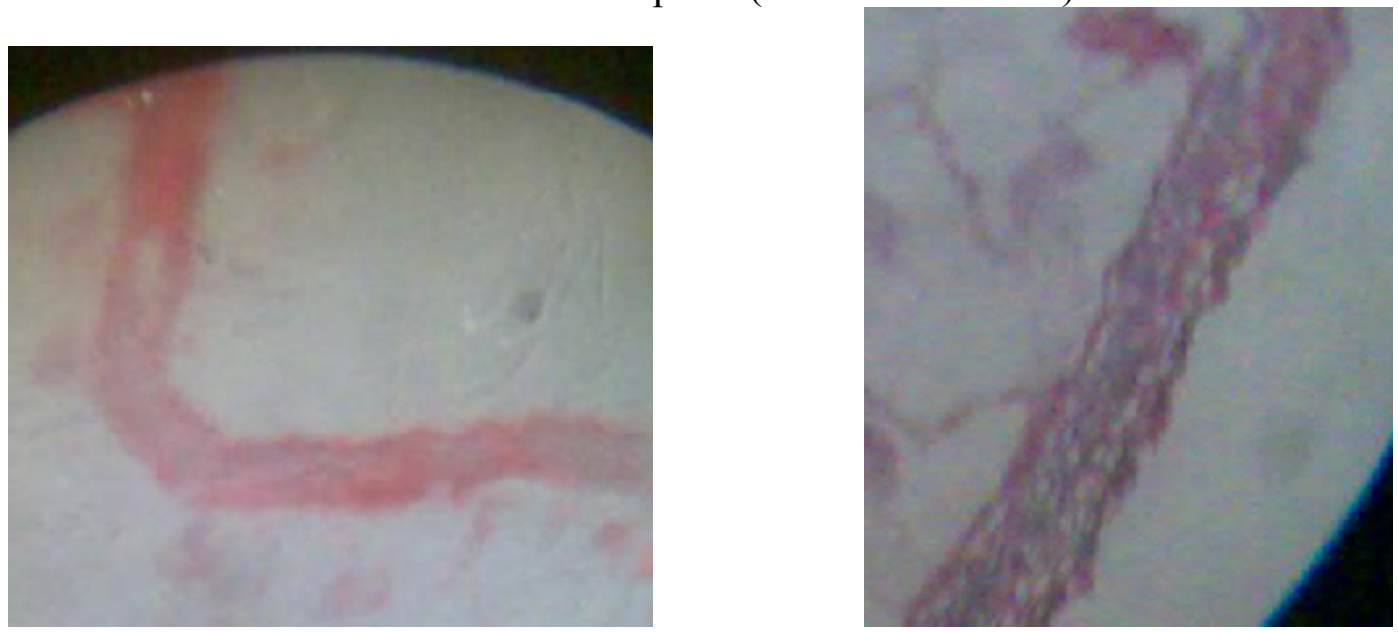

photo $(3,4)$

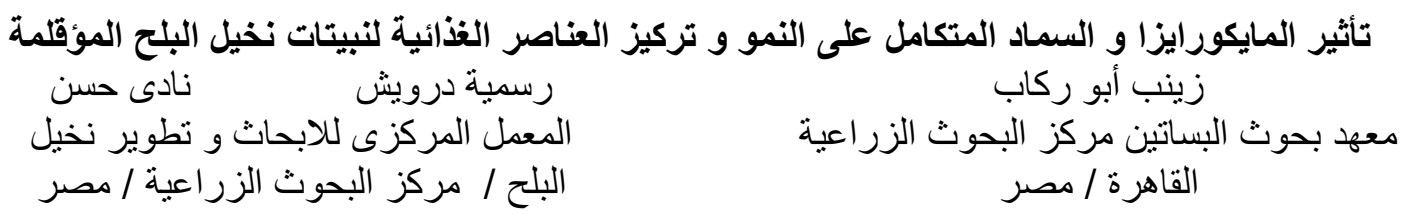

\section{الخلاصة}

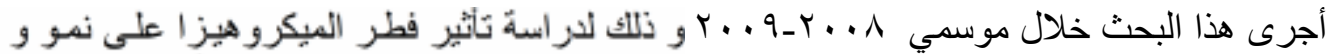

امتصاص العناصر الغذائية لنبيتات نخيل البلح صنف Bartomouda . و بعد عام من مرحلة ألاقلمة لثنبيتات

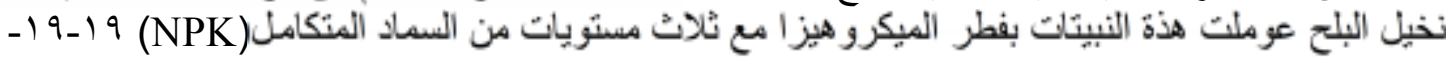

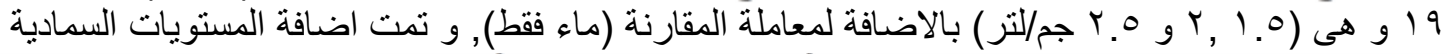

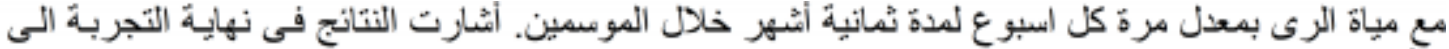

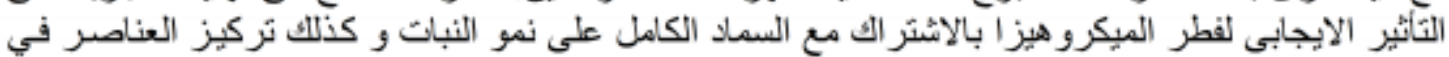

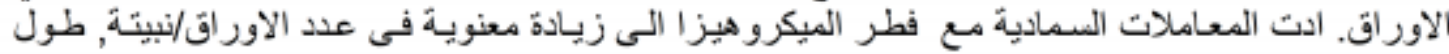

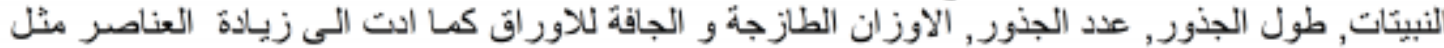

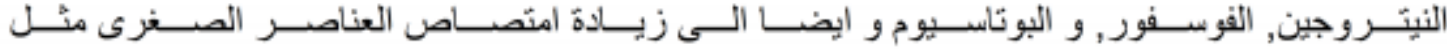

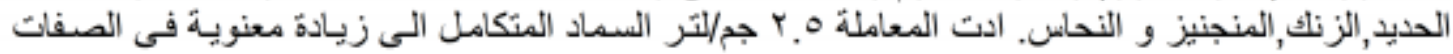

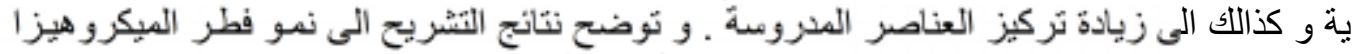

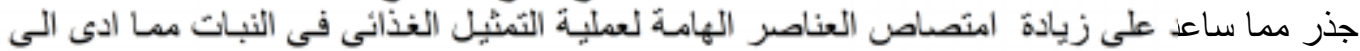

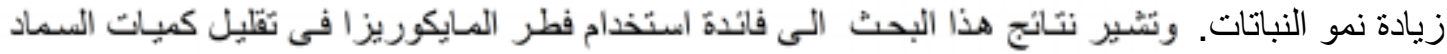




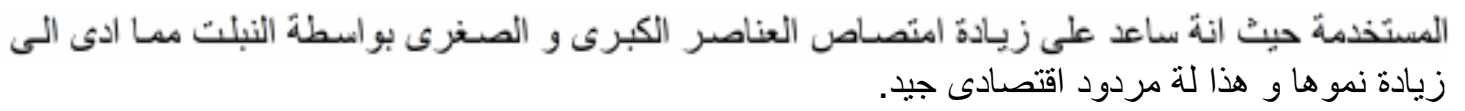

\section{REFERENCES}

Ahmed, A.M.; R. Abdelhafez, and A. Abdelmonsief,. (2009). Effect of VA mycorrhizal inoculation on growth, yield and nutrient content of Cantaloupe and Cucumber under different water regimes. Research Journal of Agriculture and Biological Sciences, 2(6):503-508

Ail,I.G.;W.;Ilson,. and A .Artnett. (2008).Effect of mycorrhizal on plant growth and dynamics in experimental tall grass prairie microcosms. American Journal of Botany, 84 (4):478-482.

Al-Agely, A. and.D Sylvia (2008).Compatible host/ mycorrhizal fungi combinations for micropropagated Sea oats: II field evaluation. Mycorrhiza, 18(5):257-261.

A.O.A.C. (1980): Association of Official Agriculture Chemists Official Method of Analysis. Washington D.C.,U.S.A. 832 pp.

Arriagada, C.A.; M.Heirera, and J.Ocampo (2007).Beneficial effect of saprobe and arbuscular mycorrhizal fungi on growth of Eucalyptus globules co-cultured with glycine $\max$ in soil contaminated with heavy metals. Journal of Environmental Management, 84(1):93-99.

Bahadur,A.;J.Siagh,.;K.Singh,.;A.Upadhyay. and M.Rai.(2009).Effect of organic amendements and biofertilizers on growth yield and quality attributes of Chinese cabbage (Brassica pekinensis (Lour) Rupe). Indian Journal of Agricultural Science, 76 (10): 596-598.

Bakhshipour, R.;E. Kahneh,. and P.Oskoei. (2008). Interaction studies of P and Zn in tea seedlings inoculated with arbuscular mycorrhizal. Asian Journal of Chemistry, 20 (2): 1175-1178.

Ben,K.L.;G.Perez,.;B.Dreyer,;A.Oihabi,;:M.Honrubia, and A. Morte (2008). Peroxidase changes in Phoenix dactylifera L. palms inoculated with mycorrhizal and bio control fungi. Agronomy for Sustainable Development, 28 (3):411-418.

Boureima,S.;M.Diouf,.;T.Diop,.;M.Diatta.;E.Leye,F. Ndiaye, and C.Seck, (2008). Effect of arbuscular mycorrhizal inoculation on the growth and the development of sesame (Sesamum indicum L.). African Journal of Agricultural Research, 3(3): 234-238.

Bucher, M. (2007). Functional biology of plant phosphate uptake at root and mycorrhizal interfaces. New Phytologist, 173(1):11-26.

Cartmill, A.D.;A.Alarcon, and A.Valdez (2008). Arbuscular mycorrhizal fungi enhance tolerance of Rosa multiflra cv. Burrto bicarbonate in irrigation water. Journal of plant Nutrition, 30(7-9):1517-1540.

Cavagnaro, T.R.;S.Sokolow, and L. Jakson (2009). mucorrhizal effects on growth and nutrition of tomato under elevated atmospheric carbon dioxide. Functional Plant Biology, 34(8):730-736.

Chapman,H.D. and F.Parker (1961).Methods of analysis for soil, plant and water. Univ.California,Div.,Agr.,Sci.

Chen,B.D.;X. Xiao.; Y.Zha,.;F.Smith.;Z.Xie, and S.Smith (2009). The arbuscular mycorrhizal fungus Glomus mosseae and arsenic acquisition by (Medicago sativa Linn). Science of the Total Environment, 379(2-3):226-234. 
Chen,B.D.;Y.Zhu, J. Duan;X.Xio and S.Smith (2007).Effect of the arbuscular mycorrhizal (Glomus mosseae) on growth and metal uptake by four plant species in copper mine tailings. Environmental Pollution, 147 (2):374-380.

Classen,V.P. and R.Zasoski (2009).Enhancement of vegetation on construction fill by fertilizer and topsoil application: Effect on mycorrhizal infection land degradation and rehabitation. Plant Sciences, 4(1):45-57.

Cline,;V. and R.Edmonds (2007). Spatial effects of retention trees on mycorrhizal and biomass of Douglas fir seedlings. Canadian Journal of Forest Research, 37(2):430-438.

Copetta, A.;G.Lingua .; G.Masoero and G.Berta2009). Influence of arbuscular mycorrhizal fungi on growth and essential oil composition in Ocimum basilicum var.genovese. Caryologia, 60(1-2):106-110.

Covacevich, F; H.Echeverria,. And L. Aguirrezabal (2009).Soil available phosphorus status determines indigenous mycorrhizal colonization of field and glasshouse-grown spring wheat from Argentina. Applied Soil Ecology. 35(1):1-9.

Deguchi,S.;Y.Shimazaki,;S.Vozumi.;K.Tawaraya,;H.Kawamoto and O.Tanaka (2007). White clover living mulch increases the yield of silage corn via arbuscular mycorrhizal fungi colonization. Plant and Soil, 29(1-2):291-299.

Demir,S.(2004).Influence of arbuscular mycorrhizal on some physiological growth parameters of pepper. Turk, Journal Biology, $28: 85-90$.

Dubois, M.;F.Smith.; K.Gilles.; J.Hamilton, and P.Rebers (1956). Colorimetric method for determination of sugars and related substances. Annal. Chem., 28 : 350-356.

Dowson, $\mathrm{V}$.and A.Aten (1962). Dates handling processing and packing F.A.O. Agricultural Development paper No. 72 Food and Agriculture Organization of the United Nations. Rome.

Duponnois,R.;C.Plenchette.;Y.Prin.;M.Ducousso.;M.Kisa,;A.Ba and A.Galiana (2007).Use of mycorrhizal inoculation to improve reafforestation process with Australian Acacia in sahelian ecozanes. Ecological Engineering, 29(1):105112.

Egerton,W..; N.Johonson and E.Allen (2009). Mycorrhizal community dynamics following nitrogen fertilization: Across site test in five grass lands. Ecological Monographs, 77(4):527-544.

Eliopoulos, T; K.Devine; P.Haydock,. and P.Jones (2007). Studies on the effect of mycorrhization of potato roots on the hatching activity of potato root leachate towards the potato cyst nematodes. Globodera pallida and G-rostochiensis. NEMATOLOGY. 9(5):719-729.

Gergon,E.B.;M.Brown, and S. Miller (2008). Enhancing yield of onion (Allium cepa L.) through mycorrhizal inoculatant in meloidogyne graminicala in fested soil. 14 Australian Agronomy conference, 21-25 sep.

George E., K. Haussler, S. Kothari, X. Li and H. Marshner.(1992). Contribution of Mycorrhizal Hyphae to Nutrient and Water Uptake of Plants. In Mycorrhizasin Ecosystems, ed., D.J. Read, D.H. Lewis, A.H. Fitter, I.J. Alexander. United Kingdom: C.A.B. International, pp.42-47. 
Grant, C. ;S.Bitman.,M. Montreal.,C. Plenchette.and C.Morel (2005). "Soil and fertilizer phosphorus: effects on plant supply and mycorrhizal development". Canadian Journal of Plant Science 85: 3-14.

Joner, E.J. (2000). The effect of long term fertilization with organic or inorganic fertilizers on mycorrhizal mediated phosphorus uptake in subterranean clover. Biology and Fertility of Soils, 32(5):435-440.

Koch,F.C. andT. McMeekin. (1924). The chemical analysis of food and food products.J.Amir.,Chem.Soc.,46:2066-2073.

Massoud, O.N. (2005).Microbiological and chemical evaluation of compost and its application in organic farming. Ph.D. Thesis, department of botany Faculty of Science, El- Menoufia, Univ. Egypt.

Massoud, O.N. (1999). Study on the effect of Azospirillum spp. VA mycorrhiza and organic matter amended soil on the plants growth. M.Sc. Thesis, Department of Botany, Faculty of Science, El.Menoufia, Univ. Egypt.

McGonigle, T.P. and M.H. Miller (1999). "Winter survival of extraradical hyphae and spores of arbuscular mycorrhizal fungi in the field".Applied Soil Ecology 12: $41-50$.

Miller, M,T. McGonigle and.H. Addy (1995). "Functional ecology if vesicular arbuscular mycorrhizas as influenced by phosphate fertilization and tillage in an agricultural ecosystem". Critical Reviews in Biotechnolgy 15: 241-255.

Mona,G.S. (2001). Response of banana and guava plants to some biological and mineral fertilizers. M.Sc. Thesis, Faculty of Agriculture, Alexandria, Univ. Egypt.

Peter, G.; K.Kennedy, andG. Peay (2009). Different soil moisture conditions change the outcome of the ecto mycorrhizal symbiosis between rhizopogon species and Pinus muricata. Plant Soil, 17(291):155-165.

Schubert,A.;C.Bodrino and I.Gribaudo (2009).Vesicular arbuscular mycorrhizal inoculation of Kiwi fruit (Actinidia deliciosa) micropropagated plants. Agronomie, 12(10):847850.

Snedecor,G.W. and W.Cochran (1980).Statistical Methods.Seventh Edition, Iowa State Univ., Press Ames., Iowa, U.S.A.

Thingstrup, I., E.Rubaek, S.Sibbensen and I. Jakobsen (1999)."Flax (Linum usitatissimum $\mathrm{L}$.) depends on arbuscular mycorrhizal fungi for growth and $\mathrm{P}$ uptake at intermediate but not high soil P levels in the field". Plant and Soil 203: 37- 46 .

Timmer, L., and R. Leyden (1980). "The relationship of mycorrhizal infection to phosphorus-induced copper deficiency in sour orange seedlings". New Phytologist 85: 15-23. 